\title{
DEMOCRACIAS NO SÉCULO XXI: CAUSAS, SINTOMAS E ESTRATÉGIAS PARA SUPERAR ${ }^{1}$
}

\author{
Marcelo Sevaybricker Moreira \\ Professor adjunto do Departamento de Ciências Humanas da
}

Universidade Federal de Lavras (UFLA). Lavras, MG, Brasil. E-mail: marcelomoreira@ufla.br.

Orcid: 0000-0002-3255-5532

http://dx.doi.org/10.1590/0102-015049/111

\section{Introdução}

Este trabalho pretende fazer um mapeamento e uma análise crítica das principais hipóteses da literatura especializada sobre a crise das democracias no século XXI. Nos últimos anos, estudiosos de diversos países vêm desenvolvendo pesquisas que identificam um processo de crescente erosão de sistemas democráticos, alguns deles tidos, até então, como muito ou relativamente estáveis, e outros como pouco estáveis. Crise, colapso, declínio, drama, desconsolidação, desdemocratização, guinada autoritária, mal-estar, recaída, recessão, retrocesso, risco e ruptura - são muitos os termos utilizados pelos estudiosos para descrever esse processo. O número de casos identificados por esses trabalhos também não é de pouco monta: Estados Unidos, França, Espanha, Reino Unido, Grécia, Itália, Holanda, Áustria, Hungria, Polônia, República Tcheca, Rússia, Ucrânia, Índia, Turquia, Filipinas, Venezuela, Bolívia, Paraguai e Brasil. A lista de nações, bem como os termos para designar esse processo, muda ao sabor do vento (pela própria natureza contingente

1 Agradeço aos pareceristas anônimos da Lua Nova pelas sugestões e comentários. 
desses processos históricos em curso) e também se modifica conforme o interesse particular de cada analista (em geral, mais voltado para os Estados Unidos, no período posterior à eleição de Donald Trump, até porque boa parte desses autores trabalham como pesquisadores nesse país).

Ao que parece, não são meros casos isolados, ou nos quais é constatado simplesmente uma queda de legitimidade das instituições de representação política, fenômeno investigado há bem mais tempo pelas ciências humanas. Ou como se pergunta David Runciman, "quais são os fatores que distinguem a crise atual das outras que a democracia enfrentou no passado, quando era mais jovem?" (2018, p. 12).

O que esses estudos asseveram é que mesmo que associado ao problema anterior (ainda não superado), a crise das democracias no século XXI configura um cenário mais grave, pois envolve outros e inúmeros fatores de instabilidade política, social e econômica, além da emergência ou fortalecimento de discursos e de práticas antidemocráticas. Essa crise não consiste no mero descrédito das democracias representativas, nem tampouco - importa destacar - se consubstancia nos riscos clássicos de subversão da ordem política, pela violência armada, através dos clássicos golpes de Estado. A ameaça às democracias no século XXI não parece, destarte, ser bem representada por tanques que ocupam as ruas e pela deposição armada de presidentes, como ocorreu no Brasil e no Chile, em 1964 e 1973, respectivamente, mas por um processo de deterioração gradativa, quer dizer, por um tipo de ruptura ou subversão institucional e social mais sutil e interna à própria dinâmica democrática. Portanto, uma crise com sintomas não tão evidentes como os antes observados no século passado.

Contudo - cumpre questionar -, será que esses casos podem ser compreendidos como partes de uma mesma tendência mundial, como alegam esses escritos? Por quê? E quais seriam, por outro lado, as especificidades nacionais 
que não devem ser desconsideradas? Xenofobia e imigração, por exemplo, parecem, de partida, serem fatores mais salientes da crise da democracia em alguns países, como a Inglaterra, mas não em todos, como Paraguai e Brasil, por exemplo. Do mesmo modo, a maneira como as elites políticas e financeiras lidaram com a crise financeira de 2008, ou a deslegitimação do sistema político por conta de escândalos de corrupção também parecem ser elementos mais determinantes em algumas democracias do que em outras. Por que, então, conceber todos esses casos como compondo parte de uma mesma crise mundial?

São muitas, em suma, as perguntas suscitadas por esses escritos. Neste artigo, me contentarei em destacar os principais ganhos e limites analíticos desses estudos para a compreensão do fenômeno em tela. Para tal, avaliarei cinco livros sobre a crise das democracias contemporâneas, recém-publicados no Brasil. São eles: Sobre a tirania (Snyder, 2017), Ruptura (Castells, 2018), Como as democracias morrem (Levitsky e Ziblatt, 2018), Como as democracias chegam ao fim (Runciman, 2018) e $O$ povo contra a democracia (Mounk, 2019). ${ }^{2}$

$\mathrm{Na}$ primeira seção deste artigo, discorro sobre o que poderíamos chamar de causas e/ou sintomas da crise, isto é, quais fenômenos são recorrentemente identificados como fatores que produziram a crise, e/ou quais são as evidências de que determinado país passa por um processo de crise de sua democracia. Justifico o porquê de não tratar

\footnotetext{
2 Não faz parte do escopo deste artigo analisar detalhadamente os argumentos e dados apresentados por esses livros. O seu desiderato é analisá-los criticamente, procurando sintetizar os principais pontos de convergência e de divergência entre eles, de modo que se evidencie também os pontos frágeis e fortes das teses que esposam sobre a crise das democracias. Esta análise tampouco pretende ser um mapeamento exaustivo de todos os estudos sobre a crise das democracias contemporâneas até então publicados, mas apenas uma primeira análise feita sobre livros se tornaram best sellers e/ou que foram escritos por acadêmicos de renome internacional e que, uma vez traduzidos para o português, podem ter, inclusive, um papel importante na formação do entendimento geral da crise que nós próprios, brasileiros, estamos vivenciando.
} 
em separado esses dois elementos: nem sempre a relação de causalidade entre os eventos é bem esclarecida pelo texto analisado; outras vezes, um elemento que é tido como um efeito, ao ocorrer, torna-se também causa da crise, como, por exemplo, a radicalização ideológica: ela não apenas evidencia a desestabilização do sistema democrático (um sintoma), como tende a agravar esse processo (uma causa).

Na segunda seção deste trabalho, abordo comparativamente esses livros a partir de suas propostas para a superação desse processo de crise. Como tentarei demonstrar, quase a totalidade desses estudos se colocam numa posição defensiva e procuram indicar estratégias para a reconstrução (ou para a preservação, a depender do caso) da democracia liberal, isto é, os sistemas políticos marcados por competição não violenta do poder, pelo sufrágio popular e pelas liberdades típicas do chamado Estado de direito. ${ }^{3}$ Pela análise aqui exposta, evidenciam-se duas estratégias propostas por esses livros. Primeiramente, o que chamo de "salvacionismo elitista", quer dizer, a aposta no restabelecimento de normas e hábitos fundamentais ao funcionamento de uma democracia a partir da ação providente e decisiva das elites políticas. Em segundo lugar, o "catecismo cívico", isto é, a estratégia que apela aos valores públicos e à mobilização dos cidadãos comuns (a serem, inclusive, "educados" pela leitura desses livros), para o restabelecimento da democracia liberal. Espera-se, em suma, que por meio de uma das duas estratégias (ou de ambas), a democracia liberal, tal como (supostamente) conhecemos no século passado, seja, enfim, restaurada, para que "as coisas voltem à normalidade".

\footnotetext{
${ }^{3}$ Estou plenamente ciente da parcialidade e incompletude dessa definição de democracia, mas a adoto, nesse passo, porque é aquilo que está pressuposto por esses próprios estudiosos. Ao longo e, especialmente, ao final deste artigo, problematizarei topicamente essa abordagem tão usual e tão pouco crítica. Entretanto, não foi possível, no espaço deste artigo, avaliar com mais vagar a concepção de democracia esposada por esses escritos.
} 
Na última parte deste artigo, para fundamentar minimamente uma avaliação crítica sobre essas cinco obras e apresentar uma compreensão alternativa para muitos dos fenômenos tratados por esses autores, volto-me à obra do sociólogo alemão Wolfgang Streeck (2002; 2018). Se são enganosos, tanto o "salvacionismo elitista" quanto o "catecismo cívico", adotados por esses cinco autores (em maior ou menor medida), tampouco se encontra na perspectiva de Streeck uma "solução" para o impasse que as democracias vivenciam no século XXI.

\section{As causas e/ou sintomas da crise}

Em um curto ensaio sobre a tirania que se tornou best seller nos Estados Unidos, o historiador de Yale, Timothy Snyder, associa o presente contexto às primeiras décadas do século XX, momento de ascensão de variantes do autoritarismo. Partindo da ideia de que podemos aprender com a história e se dirigindo ao público estadunidense governado por Trump, afirma: "os americanos não são mais sábios do que os europeus que viram a democracia dar lugar ao fascismo, ao nazismo ou ao comunismo no século XX. Nossa única vantagem é poder aprender com a experiência deles. E este é um bom momento para isso" (2017, pp. 14-15).

Em capítulo dramaticamente intitulado "No claro-escuro do caos", Manuel Castells encerra sua obra, Ruptura, comentando que uma nova política poderá surgir no futuro próximo, que "substitua a obsoleta democracia liberal que manifestamente, está caindo aos pedaços em todo o mundo" (2018, p. 144). Ao lado da possibilidade de uma nova ordem política que reconstrua a legitimidade da democracia, em geral, pondera o sociólogo espanhol, há, contudo, ameaças como o neofascismo, a volta das ditaduras, a afirmação do poder das máfias e das teocracias fundamentalistas, dentre outros riscos a serem enfrentados.

David Runciman, autor de Como as democracias chegam ao fim, afirma que "a democracia ocidental está atravessando 
uma crise de meia-idade" (2018, p. 11), sugerindo que essa crise pode ser passageira, mas pode ser também fatal para essa "jovem senhora". Ainda que assevere que dificilmente todas as democracias terão o mesmo fim e de que esse pode ser muito postergado ou mesmo evitado, em outra passagem, sustenta: "hoje, a democracia nos parece cair aos pedaços. O que não quer dizer que seja irrecuperável. Ainda não" (Runciman, 2018, p. 12).

Embora critique a tese de que estaríamos vivendo, a rigor, uma "recessão democrática" (Levitsky e Way, 2015), tida como exagerada, Steven Levitsky, em afamado livro escrito em coautoria com Daniel Ziblatt, mostra-se fortemente preocupado com a prática corrente de que, por vias democráticas, promova-se a extinção da própria democracia. "O período 1990-2015", avaliam eles, "foi facilmente o quarto de século mais democrático da história mundial [...]. Isso pode estar mudando agora” (Levitsky e Ziblatt, 2018, p. 195).

20 O cientista político alemão, radicado nos EUA, Yascha Mounk, com alguma diferença em relação à avaliação dos autores antes mencionados, salienta que recente relatório da Freedom House indica que, em 2018, entramos no " $13^{\circ}$ aniversário de uma 'recessão democrática': em cada um dos últimos treze anos, mais países se afastaram da democracia do que foram em sua direção" (2019, p. 9). Trata-se, na sua avaliação, de uma reversão da tendência de expansão das democracias no globo, verificada no pós-guerra, o que justificaria caracterizar nossa época como "tempos extraordinários", isto é, aqueles períodos históricos nos quais os contornos fundamentais da vida social estão sob judice.

Ora, considerando os cinco livros supramencionados, quais seriam as causas e os sintomas que evidenciam que determinada nação está passando por um processo de crise de seu regime democrático?

Como já disse, um certo mal-estar nas democracias contemporâneas vem sendo diagnosticado há alguns anos, 
por meio do crescimento do absenteísmo eleitoral, do decréscimo na filiação e na identificação partidárias, bem como por meio da queda da confiança nas instituições e nos políticos profissionais. Longe de ser fenômeno novo, a ciência política contemporânea tem procurado examinar as razões da crise de legitimidade das instituições de representação política, como os partidos e o poder legislativo, em particular, e de outras instituições, tidas como fundamentais às democracias representativas, como o poder judiciário. Quase todos esses estudos reiteram esse malaise. Porém, vão além disso, ao associar essa crise de legitimidade das instituições políticas a outros e novos fatores que tornaram o cenário atual mais dramático, ou que associados a ele, redundaram em novos fenômenos da cena contemporânea.

Uma primeira ressalva a ser feita a esse respeito, como nota Castells, é que a crescente desconfiança dos cidadãos comuns em relação à "política tradicional" não significa uma desconfiança em relação à democracia, em si, ou menos ainda uma defesa de soluções não democráticas. O que significa dizer que mesmo onde cresceu o número de cidadãos insatisfeitos com as democracias nos últimos anos, não há necessariamente um maior número de pessoas favoráveis a soluções autocráticas. Ao que parece, essa crise de legitimidade está mais associada à desconfiança em relação às instituições tradicionais de representação política das democracias contemporâneas, do que uma descrença direta em relação à democracia. "O que mais observo é que cada vez mais menos gente acredita nessa forma de democracia, a democracia liberal, ao mesmo tempo que a grande maioria continua defendendo o ideal democrático" (Castells, 2018, p. 16).

Porém, por que os cidadãos comuns desconfiam tanto da política institucional hoje? Parece mais ou menos consensual entre esses analistas que os escândalos de corrupção envolvendo políticos e partidos de direita, centro e esquerda são um elemento central para o crescimento do descrédito 
das instituições da democracia liberal. "Que se vayan todos" disseram os argentinos em 2001, mas também os espanhóis, em 2011, desencantados com o desempenho dos políticos de todo o espectro partidário, expressando um sentimento razoavelmente comum em diversos países do mundo, que consiste em ver as elites políticas como invariavelmente corruptas.

Sobre isso, Castells pondera que se desenrola na atualidade uma verdadeira "política de escândalo" (2018, pp. 27-28), segundo a qual cada ator político procura, no varejo, explorar midiaticamente as acusações contra seus adversários. Entretanto, o resultado da "política de escândalos", no atacado, é a preocupante autodestruição da legitimidade de todo o sistema político. Assim, a corrupção sistêmica e o uso de denúncias envolvendo políticos e partidos que organizam a disputa eleitoral têm sido vistos como uma causa importante do declínio das democracias liberais e também da ascensão de outsiders. Emmanuel Macron, 22 por exemplo, avalia Castells, é uma figura exemplar dos “profissionais apolíticos, virgens de corrupção" (2018, p. 79), que, num cenário de desprestígio de todo sistema partidário, conseguiu ascender ao poder, posicionando-se como se fosse independente a ele.

Aliado à desconfiança crescente dos cidadãos em relação a seus dirigentes, está o processo de burocratização da política, elemento típico da era Moderna (portanto, bem mais antigo do que a recente "desconsolidação democrática"), visto como um fator que tende a agravar a não identificação entre governantes e governados. Embora a maior parte dos especialistas não tome esse elemento como um fator próprio de crise - assumindo, portanto, as democracias contemporâneas como sistemas políticos inevitavelmente burocratizados alguns deles (em particular Castells, ao que parece, mais atento às reivindicações de alguns movimentos sociais que requerem maior participação popular nas sociedades contemporâneas, do que os demais autores aqui avaliados), 
afirmam que a crise das democracias é também expressão da falência de um certo modo de se fazer política, muito atrelado a interesses corporativos e elitistas, e que tende a ignorar as necessidades mais imediatas da população.

O processo de burocratização anda ao lado, pois, do crescente poder que tecnocratas (públicos ou privados) e grandes grupos empresariais têm hoje sobre as decisões em regimes democráticos. Ambos os fenômenos simbolizam uma dramática perda do povo em decidir como se quer viver coletivamente, a despeito da vigência do sufrágio universal nesses países. Castells menciona que grandes empresas como Google e Facebook, por exemplo, têm, em certo sentido, mais poder do que um presidente da República ou um premiê. Ainda que não possam competir com o Estado em relação a seu poder coercitivo (e, sob certos aspectos, dele dependam), a proximidade dessas empresas com os cidadãos comuns e seu poder de convencimento e influência é muito maior do que o que tem o aparato estatal.

Ligado ao fenômeno, ele ressalta como os novos meios de ação propiciados pela revolução tecnológica acentuaram ainda mais a distância que separa os cidadãos comuns do sistema político. Enquanto os primeiros se informam, se comunicam e se organizam a partir de múltiplas redes sociais, a política institucional, grosso modo, continuou a operar segundo os mesmos modelos tradicionais de ação. Embora esse não seja um fator sempre destacado por esses estudos como causa ou sintoma da crise das democracias, as novas tecnologias e sua influência sobre a vida cotidiana têm um impacto evidente sobre esse processo, como, por exemplo, através da difusão de informações falsas. A esse respeito, Runciman (2018, p. 134) comenta:

Na versão política do pesadelo, nossa dependência dessa tecnologia nos deixa prontos para sermos explorados. Quem vai nos escravizar não serão robôs assassinos. 
Bastam indivíduos inescrupulosos capazes de usar as máquinas em seu benefício. Em terra de dependentes da tecnologia, quem navega com esperteza é rei.

Sob esse aspecto, enquanto alguns partidos e líderes parecem ainda não ter compreendido as profundas mudanças em curso na sociedade hodierna, outros delas se aproveitaram estrategicamente e de um modo evidentemente nocivo, um modo para o qual a democracia representativa ainda não possui remédio, como, por exemplo, através da utilização das informações falsas ou distorcidas e de robôs durante as campanhas eleitorais. Trump, ele próprio, originalmente, um showman, é representativo desse novo tipo de liderança que se notabiliza em usar as novas mídias e as redes sociais, difundindo inverdades a torto e a direito, para manter sempre a atenção do público para si, mesmo que por razões negativas. Snyder, por exemplo, analisa vários desses casos no livro Na contramão da liberdade (2019), como a campanha para desinformar e manipular cidadãos em todo mundo quando a Rússia invadiu a Ucrânia (de modo a sugerir por meio dessas fake news que o exército russo não tinha qualquer participação na deposição do governante daquele antigo território da URSS). Considerando esse dentre outros casos, em Sobre a tirania, o autor apela a seu leitor: "faça um esforço para afastar-se da internet. Leia livros" (Snyder, 2017, p. 57).

Em tom igualmente moralista e quase de lamento, Mounk ressalta que quando os meios de comunicação de massa estavam sob o controle das elites políticas, era possível impedir a disseminação de discursos extremistas e de ódio, o que teria propiciado maior estabilidade às democracias. Com a adoção das novas tecnologias da informação, por meio da internet, tal cenário foi drasticamente modificado. Mesmo assim, até 2014, argumenta esse autor, preponderava entre os analistas um "tecno-otimismo", segundo o qual 
essas novas mídias eram vistas como fatores que propiciariam maior participação política e mais liberdade aos cidadãos. A partir da eleição de Trump, pondera ele, o que reina hoje é um "tecnopessimismo" (Mounk, 2019, pp. 173-175).

Ao lado também do poder econômico das multinacionais (dentre as quais se destacam algumas ligadas ao setor de tecnologia, como se disse), os autores têm destacado igualmente a restrição da vontade popular em funções de certas decisões tomadas por tecnocratas. Um caso lembrado por eles é o da Grécia, de Alexis Tsipras. Como se sabe, no cenário de forte recessão econômica, pós-2008, que atingiu também o berço da democracia ocidental, o primeiro-ministro grego convocou, em 2015, um plebiscito popular a fim de decidir a respeito das medidas de austeridade propostas ao país pelo Fundo Monetário Internacional, pela Comissão Europeia e pelo Banco Central Europeu. O resultado foi um surpreendente e estrondoso "não" da população grega ao acordo econômico proposto. Entretanto, uma semana depois do resultado do pleito, Tsipras, em reunião a portas fechadas com as elites políticas e financeiras em Bruxelas, assinou o acordo, contrariando explicitamente a vontade popular que se manifestara a seu pedido. A esse respeito, Mounk destaca que o século XXI nos brindou com uma novidade: um sistema político liberal (dado que respeita as liberdades individuais e a independência entre os poderes), mas antidemocrático, revelando que a vontade popular pode ser meramente descartada, quando contraria os interesses das grandes corporações. Nesse caso, há Estado de direito, mas não democracia.

Já que falamos de capital, a crise econômica de 2008 parece ser igualmente um fator incontornável a todos esses estudos. Ainda que com ênfases distintas, todos eles concordam que a atual crise da democracia é inseparável da última crise do sistema capitalista, na medida em que levou milhões de pessoas a serem privadas de condições mínimas de vida. 
Desemprego, precarização das condições de trabalho, aumento da pobreza, corte nos gastos públicos, desmonte das políticas de bem-estar etc., são vistos como elementos que compõem o cenário de recessão no qual os cidadãos, então, furiosos e frustrados, se "rebelaram" contra o sistema político, saindo às ruas, pedindo a deposição de alguns governantes e também por vezes elegendo candidatos que se apresentavam, oportunamente, contra os interesses das elites. Há um tom crítico comum a esses escritos quanto ao crescimento das desigualdades sociais nas sociedades capitalistas, quando se compara a segunda metade do século passado com o presente século. ${ }^{4}$

Chegamos nesse passo a um sintoma tido como típico da atual crise das democracias liberais: a eleição de candidatos que se colocam ao lado do povo contra o sistema político e econômico vigentes. Os estudos aqui avaliados veem na eleição desses outsiders um sintoma ou um efeito do descontentamento popular no cenário contemporâneo. Trata-se de lideranças que souberam aproveitar e capitanear o sentimento antiestablishment, receberam apoio de parte das elites políticas tradicionais e conseguiram, assim, chegar ao poder, como Macron na França, aqui já citado. Levitsky e Ziblatt lembram inúmeros casos anteriores nos quais essa elite acreditou poder usar e domesticar as lideranças populares antissistema, mas que acabaram fracassando em seu intento, como teria ocorrido com Hitler na Alemanha e com Mussolini na Itália. O argumento desses autores, assim como de Snyder e Mounk, é que deveríamos prestar atenção a esse período do passado - o da ascensão do "totalitarismo" para se prevenir dos males do presente.

\footnotetext{
${ }^{4}$ Não há, contudo, nesses escritos, muita clareza teórica a respeito da relação entre democracia e capitalismo, mas a premissa genérica adotada é que a primeira pode ser recuperada com a melhora e expansão do segundo - e de que essas duas realizações são, no século XXI, factíveis. Voltarei a essa discussão ao final deste artigo.
} 
Sobre os outsiders, Snyder, por exemplo, analisa detidamente o caso do financiamento eleitoral e da ação de hackers russos na campanha para levar Trump ao Salão Oval, como parte da estratégia de Vladimir Putin para minar a democracia e o império estadunidense, estratégia essa adotada em diversas nações da Europa, com o propósito de eleger outsiders que possam colaborar na consecução dos objetivos da Rússia. Também sobre isso, Mounk diz expressamente que os últimos dois decênios constituem o "momento populista", ainda que isso não signifique supor uma "era populista” (2019, p. 17). Um populismo autoritário, de acordo com o qual a vontade popular dispensa a mediação das instituições, das normas etc., dado que alguns líderes apresentam soluções simples e diretas para problemas assaz complexos, falando em nome do povo, contra as elites dominantes e o "sistema", apelando por uma sociedade melhor e mais justa, etc. Sobre isso, complementa Runciman (2018, p. 73):

A ideia básica por trás do populismo, de esquerda ou de direita, é que a democracia foi roubada do povo pelas elites. Para que seja recuperada, as elites precisam ser expulsas das suas tocas, onde escondem suas verdadeiras intenções por trás de um suposto apego à democracia.

Mounk (2019, p. 10), que recorre sistematicamente à noção de populismo para tratar da crise das democracias hoje, exemplifica o que entende por essa noção a partir do caso brasileiro:

O que define o populismo é uma reivindicação de representação exclusiva do povo - e é essa relutância em tolerar a oposição ou respeitar a necessidade de instituições independentes que com tamanha frequência põe os populistas em rota de colisão direta com a democracia liberal. Desse modo, a eleição de Jair Bolsonaro deve ser 
encarada como o evento mais significativo na história brasileira desde a queda da ditadura militar: pelos próximos anos, o povo terá de lutar pela própria sobrevivência da democracia liberal.

Sob esse aspecto, o crescente número de cidadãos, inflamados pelos populistas, que veem as próprias instituições do Estado democrático de direito como um empecilho para se alcançar tal sociedade, e que se manifestam publicamente nesse sentido - quer por meio de protestos de rua, quer por meio das redes sociais -, deveria já soar como um alarme para aqueles que estão comprometidos com a democracia liberal, avaliam esses autores.

Além da emergência do "populismo" como uma ameaça às democracias, todos esses autores compreendem que o crescimento significativo de grupos de extrema direita constitui um problema político de primeira ordem no século XXI. 28 Mesmo em lugares em que eles ainda não governam propriamente, seus líderes e seus partidos - com lemas e pautas fascistas, xenófobas, racistas etc. - têm conquistado cada vez mais espaço no sistema político e na esfera pública. O Partido da Independência do Reino Unido (UKIP), o Partido da Liberdade, na Áustria, o Lei e Justiça, na Polônia, o Fidezs - União Cívica Húngara, o Partido para a Liberdade, na Holanda, são alguns dos inúmeros casos de agremiações partidárias que contam com crescente apoio do eleitorado, sobretudo, entre sua parcela mais jovem que, explica Mounk, não passou pela experiência traumática do fascismo e da guerra. São grupos reacionários, cuja pauta invariavelmente invoca a necessidade de restauração da tradição familiar e religiosa (contra a reivindicação de grupos minoritários e/ou identitários, como mulheres, negros etc.), o fortalecimento da nação e de sua identidade comunal, a limitação da imigração ou mesmo a imediata expulsão dos imigrantes de seu território, o recrudescimento da repressão 
policial e a restrição de direitos fundamentais como solução para o problema da violência e da insegurança (como aquela causada pelo terrorismo) etc.

Snyder avalia que o discurso nacionalista tem crescido nesse contexto de crise das sociedades europeias, o que o faz rememorar o período de ascensão do fascismo e do nazismo, como se disse. Aliado à ideia de unidade da nação, ele nota o crescimento também dos discursos racistas, como aquele construído a fim de deslegitimar a aproximação do governo da Ucrânia com a União Europeia (concebida, segundo essa narrativa, como uma ameaça existencial ao povo eslavo, do qual fariam parte tanto ucranianos, quanto russos) e de legitimar sua invasão por Putin. Esses discursos apelam ao que ele chama de "política de eternidade", uma visão que postula a existência de um ideal etéreo a ser construído politicamente. $\mathrm{O}$ mesmo estratagema retórico foi adotado no "Make America great again", de Trump. Contra isso, esse historiador alerta para que seu leitor "revolte-se contra o uso traiçoeiro de vocabulário político” (Snyder, 2017, p. 95).

Cumpre destacar que, em alguns casos, sobretudo, na Europa e nos Estados Unidos, a questão da imigração é central na crise da democracia. Mounk pondera que o problema se dá não apenas nos países onde ocorre realmente uma intensa entrada de imigrantes, mas sim, onde o medo de que eles venham a ser maioria contra o "povo original" é instrumentalizado e utilizado pelos populistas de direita: "o medo que populações nativas possam deixar de ser maioria é forte até onde, à primeira vista, parece haver pouca razão objetiva para achar que isso possa acontecer num futuro próximo" (Mounk, 2019, p. 211), como seriam os casos da Hungria e da Polônia, que não sofrem propriamente com esse problema.

Com relação ao ressurgimento do conservadorismo, cumpre notar uma avaliação comum a quase todos esses escritos: o entendimento de que a defesa dos valores cristãos, da supremacia branca, da família mononuclear etc., é, 
em grande medida, uma reação (ainda que irracional) contra o crescimento dos movimentos identitários, de negros, mulheres, LGBTs etc., no final do século XX e início do XXI. Vladimir Putin é aqui lembrado como o protótipo desses líderes conservadores, ele próprio apresentado como personificação da virilidade, dentre outros valores a serem defendidos, e que usa de todo tipo de falsidades e de ofensas às minorias para angariar apoio político, associando as pautas identitárias como um inimigo comum a ser combatido. Sob esse prisma, a União Europeia era apresentada tanto pelo discurso governista russo, quanto por meios de comunicação de massa de apoio ao regime, como estando sob o verdadeiro "domínio de um lobby LGBT" (Snyder, 2019, p. 163). Para Castells, o sucesso do discurso conservador adotado por lideranças como Trump "tem raízes profundas na humilhação identitária e na marginalização social sentida por amplos setores populares" (2018, p. 58). Mounk vai 30 além, pois se o ressurgimento do "nacionalismo excludente" está diretamente relacionado à ascensão da política identitária, alguns cientistas sociais, atentos a esses movimentos sociais importantes, acabaram questionando de modo, a seu ver, excessivamente radical a legitimidade da democracia liberal e contribuíram para a reação conservadora. “A solução, portanto, não é descartar as promessas universais da democracia liberal em prol dos direitos e deveres enraizados em comunidades étnicas ou religiosas específicas, mas lutar para que enfim sejam colocadas em prática" (Mounk, 2019, p. 246).

Percebe-se em alguns desses textos, pois, um tom condescendente em relação ao conservadorismo (visto, segundo a sua ótica, como um efeito natural do avanço da esquerda identitária) e que vê com muitas ressalvas as críticas feitas nas últimas décadas à democracia liberal, como aquelas que denunciam sua parcialidade e ineficiência em promover direitos e liberdade para todos. 
O surgimento de grupos políticos sufragados pelo povo que se colocam contra os direitos de certas minorias nos leva também à segunda parte do interessante argumento formulado em $O$ povo contra a democracia. Mounk entende que, ao lado dos regimes liberais, mas não democráticos grupo no qual se enquadraria a Grécia, a União Europeia, dentre outros -, surge uma segunda forma política da cena contemporânea: as democracias iliberais. Nelas, a vontade popular é respeitada, mas há a retirada ou o desrespeito de garantias constitucionais. Nesse segundo caso, argumenta esse autor, pode-se falar ainda em democracia, mas não mais em Estado de direito. Em sua obra, o argumento é exemplificado de diversas formas. Ele lembra do plebiscito realizado na Suíça, em 2009, no qual a população de um pequeno vilarejo foi consultada a respeito do direito dos habitantes muçulmanos de construírem um minarete no local. O resultado frustrou a pequena comunidade turca e a Constituição suíça passou a determinar agora paradoxalmente que "a liberdade de religião e de pensamento é garantida [...] a construção de minaretes é proibida” (Mounk, 2019, p. 68). O segundo caso de democracia iliberal mencionado por esse autor (bem como por todos os estudiosos aqui avaliados) é a Hungria, governada ininterruptamente há nove anos por Viktor Orbán. Se no caso do minarete fica evidente como que mesmo em uma sociedade ainda liberal e democrática, a Suíça, o Estado de direito pode ser pontualmente limitado, no caso húngaro se tem um regime legitimado pelo voto popular, mas com sistemática violação aos direitos fundamentais, como a liberdade de imprensa ou de cátedra, por exemplo. Considerando, em resumo, os dois principais riscos às democracias na atualidade, o autor sintetiza:

A ascensão dos populistas na Hungria e o controle tecnocrático da Grécia parecem ocupar polos opostos. Em um caso, a vontade do povo tirou do caminho as 
instituições independentes que deveriam resguardar o primado da lei e os direitos das minorias. No outro, a força dos mercados e as convicções dos tecnocratas tiraram do caminho a vontade do povo. (Mounk, 2018, pp. 28-29)

Democracia sem liberalismo, de um lado, e liberalismo sem democracia, de outro: eis os dois principais cenários que representam a ameaça típica às democracias liberais na contemporaneidade, segundo Mounk.

Há que se ter em mente, acrescenta ele, que as democracias iliberais, que surgem no alvorecer desse século, evidenciam que há, portanto, diferentes estratégias para burlar as normas e as garantias que tipificam o Estado de direito. Não é preciso, necessariamente, atos de força ou de ruptura explícita com a ordem legal. Uma recomposição dos membros para as cortes superiores do judiciário (através da manipulação das normas de indicação, doravante mais alinhados ideologicamente com as diretrizes do executivo), ou o corte de verbas públicas para órgãos da imprensa oposicionista, ou ainda a suspensão temporária de garantias constitucionais, sob a alegação de se promover a segurança contra a ameaça terrorista, por exemplo, são maneiras que vem sendo praticadas, tópica ou mais recorrentemente, em algumas nações do globo, dentre as quais se destaca a já mencionada Hungria, mas também a Venezuela, a Turquia, a Polônia e as Filipinas.

No conjunto de questões referentes à manipulação de procedimentos e normas legais para inviabilizar as oposições, um elemento que não pode ser desconsiderado é a maior recorrência da utilização do impeachment como mecanismo para se obter o poder. Honduras (2009), Paraguai (2012) e Brasil (2016) são lembrados como casos nos quais se tomou uma solução "indevida" para uma situação de crise de governo em regimes presidencialistas, o que poderia configurar uma nova tendência mundial. Nenhum dos escritos aqui avaliados, 
contudo, analisa com detalhe essa questão e tampouco qualifica esses eventos ocorridos como golpes, no sentido rigoroso do termo, diferentemente, pelo menos, de parte da literatura especializada sobre o caso brasileiro (cf. Jinkings, 2016). ${ }^{5}$

Importa lembrar que embora o conceito de golpe de Estado tenha se modificado muito ao longo dos séculos, sabe-se que, a partir do século XX, ele passou a ser mais utilizado para descrever o golpe de tipo militar, isto é, o ato de deposição do poder que tem as forças armadas como protagonistas. A esse respeito, diz Carlos Barbé (1998, p. 546):

Na grande maioria dos casos, o golpe de estado moderno consiste em apoderar-se, por parte de um grupo de militares ou pelas forças armadas em seu conjunto, dos órgãos e das atribuições do poder político, mediante uma ação repentina, que tenha uma certa margem de surpresa e reduza, de maneira geral, a violência intrínseca do ato com o mínimo possível de violência física.

Levitsky e Ziblatt (2018, p. 81) asseveram que o principal risco às democracias de hoje "não vem de fora", como uma abrupta intervenção militar:

A erosão da democracia acontece de maneira gradativa, muitas vezes em pequeníssimos passos. Tomado individualmente, cada passo parece insignificante - nenhum deles aparenta de fato ameaçar a democracia. Com efeito, as iniciativas governamentais para subverter a democracia costumam ter um verniz de legalidade.

\footnotetext{
${ }^{5}$ Desde já, cabe salientar essa lacuna, presente também no texto de Mounk: o impeachment nesses países teria produzido um Estado de direito sem democracia ou um Estado democrático sem direitos? Como classificar, por exemplo, o Brasil pós-2016 e, a partir de 2019, sob o governo Bolsonaro, de acordo com essa tipologia?
} 
Tendo em vista esse significado tradicional de golpe nas ciências humanas, esses autores interpretam os casos supramencionados, dentre os quais se enquadraria o impeachment de Dilma Rousseff, como "jogo duro constitucional". O que seria isso? Não um golpe, em seu sentido "clássico", mas um tipo de ação da oposição que "leva ao pé da letra" as leis a fim de derrubar o governo. Não há ilegalidade, dizem eles, pois os ritos foram minimamente respeitados: observou-se o direito ao contraditório, a ampla defesa, não houve fraude no processo de votação e deliberou-se, ao cabo, pelo impedimento do presidente. Entretanto, o impeachment, tal como vem sendo praticado, viola os limites da razoabilidade e destoa da prática política pregressa: "trata-se de uma forma de combate institucional cujo objetivo é derrotar permanentemente os rivais partidários - e não se preocupar em saber se o jogo democrático vai continuar" (Levitsky e Ziblatt, 2018, p. 109). O jogo duro constitucional que, diferentemente dos golpes, stricto senso, respeita a legalidade, mina, no entender desses autores, a "reserva institucional", quer dizer, a disposição dos atores políticos em "evitar ações que, embora respeitem o limite da letra da lei, violam claramente o seu espírito" (Levitsky e Ziblatt, 2018, p. 107).

Essa discussão nos leva a analisar outros fatores que, segundo esses estudos, desestabilizam as democracias: a polarização e a radicalização ideológica. Por polarização, esses estudiosos compreendem uma perda significativa de capital político dos setores moderados do espectro político, ao passo que a radicalização expressa o crescimento de grupos e atores que tendem a não tolerar seus adversários, à esquerda e à direita (especialmente). Novamente, retomando o estudo de Levitsky e Ziblatt, tal fator de crise consiste na deterioração da tolerância mútua, isto é, o conjunto de expectativas e práticas das lideranças segundo o qual a existência das oposições é vista como algo legítimo e uma eventual derrota eleitoral, como resultado normal e aceitável. 
"A tolerância mútua diz respeito à ideia de que, enquanto nossos rivais jogarem pelas regras institucionais, nós aceitaremos que eles tenham direito igual de existir, competir pelo poder e governar" (Levitsky e Ziblatt, 2018, p. 103). Ora, na medida em que a política se torna cada vez mais polarizada e que os atores assumem posições extremadas, os adversários deixam de ser vistos como oponentes legítimos e passam a ser compreendidos como inimigos, criminosos, subversivos etc. A retórica belicista se instaura e o "outro" precisa então ser eliminado. Os discursos de Trump são frequentemente lembrados por todos esses autores como sintomas de radicalização ideológica, como, por exemplo, quando ele questionou se Barack Obama havia realmente nascido nos Estados Unidos, ou quando, em um debate, disse a Hillary Clinton que, caso ele vencesse a eleição, a mandaria para a cadeia.

Ziblatt e Levitsky ponderam que, ao lado dos procedimentos formais de competição política, essas duas normas não escritas (a da reserva institucional e a da tolerância mútua) são fundamentais para constituir o que eles denominam de "grades de proteção" dos regimes democráticos. São essas grades que têm sido abaladas ou destruídas por meio do jogo duro constitucional e da crescente radicalização política.

\section{Como sair da crise?}

Depois da identificação de tantos fatores que causaram a crise da democracia e/ou sinalizam precisamente esse processo, é natural que o leitor se pergunte: mas, então, o que fazer? Como frear e reverter essa tendência ameaçadora (supondo que tal feito seja possível)? Esse leitor não ficaria sem resposta.

Dos cinco livros aqui avaliados, dois deles não apresentam propriamente "soluções" para a crise das democracias liberais (caso de Castells e Runciman). Os outros três (Snyder; Levitsky e Ziblatt; Mounk) dedicam inúmeros e longos capítulos a fim de instruir seus leitores sobre como superar essa crise. 
A despeito de depositar esperanças em movimentos sociais de renovação da política, como, por exemplo, os Indignados ou o movimento dos 15-M da Espanha, Castells avalia prudentemente que o futuro das democracias é, hoje, bastante incerto, e que tais movimentos podem ser cooptados pelos partidos ou acabar se burocratizando. Cumpre notar que tais movimentos - alguns deles, como Occupy Wall Street - importantes marcos de reivindicação de um aprofundamento da democracia até então existente, tal como reconhece Castells - são simplesmente ignorados por todos os outros autores. O autor não vai, contudo, além de identificar um impasse e um cenário de incertezas.

Runciman também não indica estratégias de superação da crise da democracia e, mais do que isso, parece ser, de fato, o menos otimista dentre os autores aqui analisados quanto a essa possibilidade (e não exatamente compromissado com isso, como sugerem algumas passagens de Como as democracias chegam ao fim). Após comparar as vantagens da democracia liberal com um sistema autoritário-pragmático, uma epistocracia (quer dizer, um governo de especialistas) e uma sociedade liberada da política pelo desenvolvimento da tecnologia, pondera:

Então, não há dúvida de que existem opções melhores que a democracia contemporânea. Os futuros mais atraentes que conseguimos imaginar incluem maneiras de fazer política que representam um evidente aperfeiçoamento do que temos agora. (Runciman, 2018, p. 219)

São, por conseguinte, nos livros de Snyder, Mounk e Levitsky e Ziblatt que o leitor encontra um conjunto de estratégias e medidas profiláticas, por assim dizer, para evitar, conter ou reverter a crise de uma democracia.

Mais do que apenas escrever algumas linhas sobre o assunto, Snyder dedica um livro inteiro para "dar lições" 
aos cidadãos contemporâneos, lições essas (suspostamente) fundamentadas na análise do passado. Em Sobre a tirania, ele estabelece uma espécie de cartilha cívica, definindo vinte máximas de conduta aos seus leitores, tais como "não obedeça de antemão", "cuidado com os grupos paramilitares", "contribua para as boas causas", dentre outras recomendações tão ou mais genéricas. Contra o que ele chama de "política da inevitabilidade", concepção muito comum na segunda metade do século XX, segundo a qual a combinação de democracia mais capitalismo constituiria o "fim da história", Snyder alerta para o processo em curso de reversão de direitos e de liberdades, inclusive no país que se colocava como modelo, os Estados Unidos. Esse processo, segundo ele, tem sido desencadeado pela substituição da "política da inevitabilidade" pela "política da eternidade", de modo que a crença não histórica na vitória inexorável da democracia liberal vem sendo substituída pela crença no retorno a uma grandeza ou unidade do passado, no limite "fora da história". Contra esse ressurgimento da "política da eternidade" (que já havia sido utilizada no início do século XX pelos movimentos e regimes totalitários), Snyder aposta na mobilização das massas, a serem educadas por seu próprio livro. É, portanto, na ação dos cidadãos engajados e esclarecidos (aqueles que, segundo ele, ajudaram a fundar repúblicas democráticas, como os EUA), que encontraremos a saída para a guinada autoritária em curso.

Levitsky e Ziblatt, por sua vez, destacam que é imperioso estabelecer amplas coalizões democráticas que possam restabelecer as regras informais da democracia, a saber, a tolerância mútua e a reserva institucional. Os autores clamam para que as elites políticas, conscientizadas dos sérios riscos em jogo, sobretudo, os que perpassam os Estados Unidos da América, país onde residem, possam agir com sabedoria e prudência, moderando os ânimos e restituindo as boas expectativas de todos os atores quanto à competição partidária e eleitoral. 
Nesse mesmo sentido, eles argumentam que uma das estratégias que já foi e pode ser ainda decisiva para estancar a crise das democracias consiste em as burocracias partidárias vetarem as candidaturas de certos indivíduos, funcionando como "muros de contenção" contra os apelos populistas e os demagogos autoritários. Os autores apresentam, então, quatro critérios que poderiam ser facilmente utilizados pelas lideranças partidárias para identificar o comportamento autoritário de um candidato, a saber: (1) quando eles recusam a aceitar as regras do jogo, afirmando, por exemplo, que uma derrota pressuporia algum tipo de fraude eleitoral; (2) quando negam legitimidade aos seus adversários, criminalizando sua história pessoal ou posição política; (3) quando esses candidatos toleram ou mesmo instigam a violência contra seus opositores; (4) quando se mostram dispostos a restringir liberdades individuais, como por exemplo, atacando a imprensa ou as universidades, como supostas fontes de propagação de mentira contra si.

O problema, argumentam Levitsky e Ziblatt, é que as elites tradicionais, num cenário de crise de legitimidade do sistema político, se sentem frequentemente tentadas a cooptar tais líderes, a despeito de seu comportamento autoritário, na esperança de poder domesticá-los, ou de que eles serão normalizados pelos próprios constrangimentos institucionais inerentes ao governo. Como na fábula de Esopo sobre a disputa entre o javali e o cavalo, citada pelos autores, no qual o segundo aceita ser selado pelo cavaleiro para derrotar o primeiro, as elites partidárias tiveram, em casos semelhantes, seu sonho de poder frustrado porque foram elas que posteriormente acabaram submetidas pelos líderes autoritários, e não o contrário. Ao tentar estrategicamente explorar a ascensão dos populistas, essas elites acabaram colocando em risco todo o sistema político.

Como se pode constatar, assim como o livro de Snyder chama a atenção pela fé depositada pelo autor na educação e na mobilização dos indivíduos comuns (concebidos 
como instrumento de luta contra a ascensão autoritária), o livro Como as democracias morrem deposita as esperanças de se "salvar a democracia" quase exclusivamente na classe política tradicional, que teria o poder de restaurar as condições de funcionamento anteriores ao seu processo de declínio. ${ }^{6}$ Segundo Levitsky e Ziblatt, as lideranças partidárias foram, tradicional e usualmente, capazes de filtrar e vetar os candidatos que representavam um risco para a democracia. Contudo, tal capacidade declinou na medida em que o poder econômico passou a incidir com mais força sobre a política (por meio do financiamento das campanhas) e em que (por meio das novas mídias) a emergência de lideranças independentes do controle partidário tornou-se possível. Assim sendo, o apelo normativo desses autores é pela reconstrução desse sistema político, tal como supostamente vivenciado na segunda metade do século XX, objetivo esse visto como viável e em torno do qual as elites políticas (no cenário obsessivamente tratado por eles, os republicanos e os democratas dos EUA) deveriam se unir.

O livro de Mounk também fala de "remédios" para conter a "recessão democrática". De modo imediato, diz ele de modo muito similar a Levitsky e Ziblatt, cumpre evitar a fragmentação do campo democrático, quando confrontado por um populista, o que, infelizmente, não se conseguiu fazer na Polônia, na Hungria, nos Estados Unidos e no Brasil. Líderes autoritários têm ganhado as eleições mesmo não conquistando a maioria absoluta dos votos. Assim, ele alerta, uma ampla frente democrático-eleitoral poderia barrar a ascensão desses candidatos ao poder. Além disso, as candidaturas do campo democrático não podem cometer o erro de se limitar apenas em apontar obsessivamente os defeitos dos populistas, mas devem ser também capazes de se "conectar

\footnotetext{
${ }^{6}$ Em poucas e breves passagens, esses autores salientam a importância da realização de protestos em defesa e pela democracia - desde que não sejam violentos ressaltam eles.
} 
com as preocupações dos eleitores" (Mounk, 2019, p. 228), apresentando propostas realistas de um mundo melhor. Os candidatos democráticos, para terem condições de competir com as soluções simplistas, mas persuasivas, dos populistas, precisam "falar a língua da gente comum" (Mounk, 2019, p. 228), isto é, criar uma narrativa de que há maneiras de se resolver os principais problemas da sociedade hodierna de forma democrática e respeitando os direitos individuais. Por fim, afirma esse autor, para rivalizar com os populistas autoritários é imprescindível questionar e se mostrar disposto a transformar o status quo. Em sua avaliação, Hillary Clinton, por exemplo, perdeu para Trump, a despeito das suas flagrantes deficiências, porque não foi capaz de convencer os eleitores de que estava realmente disposta a mudar a realidade nacional, ao passo que o atual presidente da República prometia insistentemente melhorar a vida dos estadunidenses e acabar com os privilégios da elite, como mostra sua fala, 40 reproduzida no livro de Mounk (2019, p. 30): "eu lhes peço o seguinte [...] aos afro-americanos... aos hispânicos, pessoas maravilhosas: que diabos vocês têm a perder? Me deem uma chance. Vou arrumar as coisas. Vou arrumar as coisas. O que vocês têm a perder?”.

Mas, além dessas recomendações de prudência e de estratégia direcionadas às elites políticas (solução as quais se limitam Levitsky e Ziblatt), Mounk avalia que há três questões mais estruturais que precisam ser enfrentadas:

Para salvar a democracia, precisamos, em outras palavras, unir cidadãos em torno de uma visão comum de suas nações; dar-lhes esperança verdadeira quanto a seu futuro econômico e torná-los mais resistentes às mentiras e ao ódio com que se deparam nas mídias sociais diariamente.

São esses os desafios imensos que definirão nossa luta contra o populismo, e por uma sociedade melhor, nas décadas que estão por vir. (2018, p. 232) 
O primeiro problema diz respeito ao ressurgimento do nacionalismo excludente. No cenário de uma ampla e grave crise econômica e de intensos fluxos migratórios, os populistas de direita ganharam força precisamente porque souberam mobilizar politicamente a identidade nacional, diferentemente de certos setores da esquerda, que rejeitavam totalmente a própria ideia de nação. Contra isso, pondera Mounk, seria preciso defender os princípios do Estado de direito para todos - proposta antagônica à dos populistas autoritários - incluindo obviamente os imigrantes à nação, ainda que isso não resolva totalmente a questão imigratória, para a qual, reconhece ele, não existem soluções fáceis. Ao contrário de afirmar as identidades das minorias, aumentando a fragmentação política, seria preciso que as forças democráticas propusessem um nacionalismo compatível com o Estado de direito.

$\mathrm{O}$ segundo desafio posto às democracias diz respeito às condições reais e materiais da população nesses países. O cenário de degradação econômica é um solo fértil para o populismo autoritário, pois gera desesperança e rancor do povo contra as classes mais abastadas. De um modo geral, é imperioso "consertar a economia", diz Mounk, o que, em sua visão, envolveria restaurar as bases do Estado de bem-estar social, adotando uma política de tributação progressiva, de habitação popular, qualificando melhor a mão de obra etc.

A terceira e última tarefa estrutural a ser realizada para superar a crise das democracias é "renovar a fé cívica", persuadindo as pessoas comuns quanto às vantagens e à importância da democracia liberal. Nesse aspecto, diferentemente dos autores de Como as democracias morrem, o livro de Mounk não associa a superação da crise das democracia exclusivamente ao comportamento das elites políticas, mas concebe que a defesa dos valores democráticos e liberais é tarefa necessária de toda sociedade. Como se vê, o discurso de Mounk, nesse passo, vai ao encontro às propostas de Snyder, 
de esclarecimento do público-leitor quanto à importância da democracia liberal.

Concluindo o argumento, é, nesse sentido, que o presente artigo diferencia, dentre as obras aqui analisadas e que apresentam "saídas" para a crise das democracias contemporâneas, duas estratégias. De um lado, como muito bem exemplificado pela obra de Snyder e, em parte, pela obra de Mounk, o que denomino de "catecismo cívico", isto é, um conjunto de instruções e máximas morais para capacitar a sociedade, de um modo geral, a impedir a "recessão democrática". De outro lado, o "salvacionismo elitista", quer dizer, a concepção segundo a qual a principal solução para esse processo de crise das democracias consistiria em restabelecer, entre as próprias elites partidárias e políticas, as práticas e os discursos mais moderados e comprometidos com os seus princípios básicos, solução essa, como vimos, adotada integralmente por Levitsky e Ziblatt e, parcialmente, por Mounk.

Independentemente de qual estratégia é destacada por cada um desses quatro autores (se o salvacionismo elitista ou se o catecismo cívico), todos eles presumem que a crise das democracias no século XXI é contingente e dissociada, em certa medida, das contradições inerentes à própria ordem social moderna. Ou seja, por meio de reformas e de rearranjos pontuais, seria possível restabelecer essa ordem. Snyder, Levitsky e Ziblatt, de um lado, parecem simplesmente ignorar que a crise das democracias ocorre pari passu à crise do capital (precisamente por isso, as estratégias propostas por ele passam ao largo de quaisquer considerações de ordem socioeconômica). No caso do autor de $O$ povo contra a democracia, a questão socioeconômica é observada, mas ainda marginalmente ou, o que é mais importante, não concebida a partir das próprias contradições da "democracia liberal". Cumpriria, por exemplo, perguntar a Mounk como incluir a massa de imigrantes, que vivem em condições de extrema precariedade, em uma sociedade na qual não há emprego 
nem mesmo para os cidadãos do país? Além disso, como restaurar o Estado de bem-estar social em um cenário de total débâcle econômica? Ou também como "renovar a fé cívica", se não há uma comunidade moral prévia a qual se reportar, já que, do ponto de vista dos valores e das crenças, as sociedades contemporâneas estão cada vez mais fragmentadas?

Em minha avaliação, em maior ou menor medida, Snyder, Mounk, Levitsky e Ziblatt - a despeito de instigantes reflexões produzidas diferencialmente por cada um deles - "isolam" o sistema político da realidade socioeconômica, como se ele funcionasse segundo uma dinâmica interna, regrada pelas instituições e pelo comportamento dos atores políticos, de modo que caberia à vontade e à união dos atores políticos (quer sejam os cidadãos comuns, quer sejam os políticos profissionais, ou quer se pensem nos dois grupos) superar a crise da democracia contemporânea. Daí o tom de súplica (particularmente evidente em Sobre a tirania e em Como as democracias morrem) pela restauração desse sistema, como se dependesse principalmente da deliberação desses atores tal tarefa.

Não posso deixar de mencionar também que todos esses autores (Snyder; Levitsky e Ziblatt; Mounk) tomam a democracia liberal, em especial, tal como teria sido praticada nos Estados Unidos e na Europa Ocidental, na segunda metade do século XX, como um ideal a ser, em grande medida, emulado mundo afora. Ainda que reconheçam algumas deficiências da democracia liberal (por exemplo, Mounk ao constatar que a democracia estadunidense funcionou estavelmente apenas com a exclusão dos negros da política) há, de fato, a defesa de tal sistema político, representado paradigmaticamente por alguns países do Atlântico Norte, que não deveria ser abandonado simplesmente porque entrou em declínio.

\section{Crise adiada e revolução neoliberal}

Sobre esses dois aspectos, pode-se voltar à obra de Ellen Meiksins Wood (2003), que já havia notado que o ganho 
analítico fundamental do marxismo, frente a outras abordagens de interpretação da política, é precisamente o de integrar essa dimensão com outras variáveis da vida social. Na medida em que o sistema político liberal-democrático é concebido como uma instância insulada da vida social e na medida em que ele entra em crise, tanto as causas desse processo, quanto as saídas encontradas para essa crise são essencialmente, como vimos pela análise das obras de Snyder, Mounk, Levitsky e Ziblatt, de ordem institucional, como se o próprio sistema pudesse, por suas próprias possibilidades, encontrar um ponto de equilíbrio - ideia que é apenas presumida, mas não é minimamente fundamentada.

Além dessa limitação evidente, é de se notar como a própria concepção de democracia esposada por esses autores é, ela própria, limitada e resultante de um processo histórico no qual se dissocia fortemente seu funcionamento da participação e da soberania popular. Novamente, como já 44 notou Wood, a expansão e a consolidação da democracia no século XX só se deu às custas do significado próprio desse ideal, ligado originalmente à ideia de um governo liderado e exercido em benefício da maioria, incluindo, sobretudo, as camadas mais carentes da comunidade. Dizer democracia, desde os gregos, implicava em pensar numa forma de organização social na qual a maioria exerce diretamente o poder político em prol do interesse da própria maioria o que a colocava em confronto direto com todos os grupos de privilegiados. A transformação e o esvaziamento do ideal democrático ao longo da história, especialmente a partir do final do século XIX (ideal esse que passou a se designar sistemas políticos marcados por razoável competição eleitoral entre grupos minoritários, com participação política limitada ao direito ao voto e com algum grau de efetivação de liberdades fundamentais), é peça fundamental para o adequado entendimento da crise que hoje vivenciamos, diferentemente do que fazem todos (ou quase todos) os 
estudos aqui avaliados. Destarte, talvez, mais do que dizer que a prática ou o ideal da democracia tenha colapsado no século XXI, seria mais prudente assumir que uma determinada concepção de democracia (a democracia liberal) tenha entrado em profunda crise.

Antes de encerrar este artigo, é importante avançar na avaliação crítica desses escritos, mas agora à luz de uma interpretação alternativa do que está em jogo quando dizemos que as democracias contemporâneas estão em crise. Para tal, passo a examinar, tópica e muito brevemente, a obra do sociólogo alemão Wolfgang Streeck. Longe de presumir que tal obra possa dar conta dos diversos aspectos particulares da chamada crise da democracia contemporânea (como o crescimento da xenofobia, ou o impacto dos escândalos de corrupção etc.), ou que possa esclarecer as especificidades de cada nação que vivencia essa crise, a ideia é tão somente tomar a obra de Streeck como ponto de partida para a compreensão de seus fundamentos mais gerais.

Primeiramente, cumpre destacar que ao invés de conceber essa crise como um "desvio de rota", ou como evento isolado, Streeck a interpreta como efeito mais recente de uma antiga e inevitável contradição entre uma organização politicamente democrática (que prevê a maximização dos direitos sociais e do bem-estar, por exemplo) e os mercados capitalistas (orientados pelos critérios do lucro, da contenção dos gastos públicos, pela desregulamentação financeira etc.). Estilisticamente, escreve ele, o que importa definir é qual é o desenlace histórico da tensão inerente entre o "povo do Estado" e "povo do mercado", evidenciada pela constante pressão para que se impeça qualquer tipo de intervenção política sobre a lógica de acumulação do capital (cada vez mais concebida como natural e racional, ainda que produza recorrentes desigualdades sociais a partir de uma produção que, não obstante, é socialmente compartilhada). No caso da crise das democracias no século XXI, tal desenlace se deu pela redução significativa do 
poder do "povo do Estado" e pela restauração do poder do "povo do mercado". Streeck pondera que desde o pós-guerra, o capitalismo passou a "comprar tempo", dando soluções emergenciais, mas ineficazes, a longo prazo, para a tensão supramencionada. Por "comprar tempo", o autor designa o processo pelo qual se usa o dinheiro a fim de apaziguar os conflitos sociais: primeiramente, nos anos 1940, por meio do inflacionamento da massa monetária (Estado fiscal); em seguida, nos anos 1980, pelas crescentes dívidas públicas (Estado endividado); e, por fim, na atualidade, pela expansão do crédito privado às famílias e pela subsequente compra de dívidas de Estados e de bancos pelos bancos centrais (Estado de consolidação) (Streeck, 2012, pp. 45-53). Esses três modelos de Estado podem ser abarcados no conceito de capitalismo democrático, caracterizado:

Como uma economia pautada por dois princípios ou regimes conflitantes de alocação de recursos: o primeiro opera de acordo com a produtividade marginal, ou com aquilo que é exposto como uma vantagem por um 'livre jogo das forças de mercado', e o outro se baseia em necessidades ou direitos sociais, tal como estabelecidos por escolhas coletivas em contextos democráticos. Sob o capitalismo democrático, os governos são teoricamente instados a cumprir ambos os princípios simultaneamente, ainda que eles quase nunca se alinhem de forma substantiva. Na prática, podem negligenciar um princípio em favor do outro por algum tempo, até serem penalizados pelas consequências: governos que deixem de atender demandas democráticas por proteção e redistribuição se arriscam a perder o apoio da maioria, enquanto aqueles que desconsideram as demandas por compensação dos detentores dos recursos produtivos com relação à produtividade marginal - provocam disfunções econômicas que se tornam cada vez mais insustentáveis, solapando também seu apoio político. (Streeck, 2002, pp. 37-38) 
O capitalismo democrático nada mais é, portanto, do que o compromisso histórico estabelecido no pós-guerra, que viabilizou, temporariamente, conciliar crescimento econômico com redistribuição de riquezas e oportunidades, mediante os crescimentos econômico e do endividamento dos Estados, mas que com o passar do tempo foi sendo dissolvido. $\mathrm{Na}$ esteira da descrença crescente (anos 1960) quanto à capacidade do Estado domar o capital, dá-se a "revolução neoliberal", isto é, com o suposto objetivo de solucionar a recessão econômica e o endividamento estatal restaura-se "a economia como força coercitiva social, reconhecidamente não para todos, mas para a esmagadora maioria” (Streeck, 2018, p. 16). De lá pra cá, da transformação das instituições políticas e econômicas de orientação keynesiana a um regime crescentemente hayekiano, o que tem ocorrido é um contínuo processo de "desdemocratização do capitalismo" (Streeck, 2018, p. 55), isto é, o mercado tem conseguido se estabelecer "fora" ou "acima" de qualquer controle das massas, o que obviamente não significa prescindir do Estado:

Já ficou várias vezes demonstrado que o neoliberalismo necessita de um Estado forte que trave as exigências sociais e, em especial, sindicais de interferência no jogo livre de mercado. [...] O neoliberalismo, contudo, não é compatível com um Estado democrático se entendermos por democracia um regime que intervém, em nome dos seus cidadãos e por meio do poder público, na distribuição dos bens econômicos resultantes do funcionamento do mercado. (Streeck, 2018, p. 103)

Assim, se o modelo neoliberal de Estado se mantiver, os governos democráticos vivenciarão, cada vez mais, constrangimentos de toda ordem, impostos pelo mercado, o que nos sugere que a crise das democracias no século XXI não pode ser compreendida como mera decorrência de programas 
eleitorais sufragados pelo povo (como as propostas ditas populistas), ou que podem ser decisivamente superadas pela eleição de novos governos (como através das coalizões democráticas). Trata-se, pois, de uma crise estrutural para a qual talvez ainda não tenhamos as soluções necessárias. Uma crise cujo fundamento parece residir no modelo de sociedade hegemônico, que requer uma drástica redução da soberania popular, mesmo em condições econômicas duramente recessivas. Uma crise, por fim, da democracia liberal, duramente constrangida pelos impactos da "revolução neoliberal".

Para concluir, pode-se dizer que se os escritos antes analisados (Castells, Levitsky e Ziblatt, Mounk, Runciman, Snyder) acertam, ao que parece, em identificar uma tendência mundial de crise das democracias, eles não conseguem identificar o elo comum, ou o fator que interliga tais processos nacionais. Falta a eles, em suma, uma teoria que conecte os vários processos nacionais do que vem sendo chamado de desconsolidação democrática (crise migratória, desemprego, xenofobia, crise de legitimidade do sistema político etc.). Ora, o que Streeck nos fornece é precisamente esse elo: o modelo neoliberal de Estado e de sociedade. Reconhecer isso não implica em desconsiderar a relevância de inúmeras proposições normativas apresentadas pelos autores antes tratados (como a necessidade de se barrar, nas campanhas eleitorais, candidatos autoritários, por exemplo). Por outro lado, sua análise da crise do capitalismo democrático revela os limites inerentes a essas estratégias de se "salvar" a democracia. ${ }^{7}$ Como diz Streeck, os meios até então utilizados pelo capitalismo democrático para comprar

\footnotetext{
${ }^{7}$ Um aspecto certamente limitador em comum entre a obra de Streeck e os demais autores antes analisados é o fato de que elas se baseiam quase exclusivamente nas experiências dos países da Europa Ocidental e dos Estados Unidos. Os países periféricos (que vivenciaram processos de modernização tardia e/ou conservadora, incluindo um longo histórico de autoritarismo) são quase sempre mencionados muito marginalmente e interpretados à luz da experiência de desdemocratização dos países centrais.
} 
tempo e adiar uma radicalização da crise (inflação, endividamento público, endividamento privado) já se esgotaram. $\mathrm{O}$ que vem a seguir, ainda parece ser uma incógnita.

\section{Marcelo Sevaybricker Moreira}

Doutor em Ciência Política pela Universidade Federal de Minas Gerais (UFMG). Professor adjunto do Departamento de Ciências Humanas da Universidade Federal de Lavras (UFLA). Pesquisa Teoria Política e Pensamento Político Brasileiro.

\section{Bibliografia}

BARBÉ, Carlos. 1998. Golpe de Estado. In: BOBBIO, Norberto (org.). Dicionário de Política. 11. ed. Brasília: Ed. UNB. pp. 545-547.

CASTELLS, Manuel. 2018. Ruptura: a crise da democracia liberal.

Rio de Janeiro: Zahar.

JINKINGS, Ivana. (org.). 2016. Por que gritamos golpe? Para entender o impeachment e a crise politica no Brasil. São Paulo: Boitempo.

LEVITSKY, Steven.; WAY, Lucan. 2015. The myth of democratic recession. Journal of democracy, v. 26, n. 1, pp. 45-58.

LEVITSKY, Steven.; ZIBLATT, Daniel. 2018. Como as democracias morrem. Rio de Janeiro: Zahar.

MOUNK, Yascha. 2019. O povo contra a democracia: por que nossa liberdade corre perigo e como salvá-la. São Paulo: Companhia das Letras.

RUNCIMAN, David. 2018. Como a democracia chega ao fim. São Paulo: Todavia.

SNYDER, Timothy. 2017. Sobre a tirania: vinte lições do século XX para o presente. São Paulo: Companhia das Letras.

SNYDER, Timothy. 2019. Na contramão da liberdade: a guinada autoritária das democracias contemporâneas. São Paulo: Companhia das Letras.

STREECK, Wolfgang. 2002. As crises do capitalismo democrático. Novos Estudos CEBRAP, n. 92, pp. 35-56.

STREEGK, Wolfgang. 2018. Tempo comprado. A crise adiada do capitalismo democrático. São Paulo: Boitempo.

WOOD, Ellen M. 2003. Democracia contra capitalismo: a renovação do materialismo histórico. São Paulo: Boitempo. 


\section{DEMOCRACIAS NO SÉCULO XXI: CAUSAS, SINTOMAS E ESTRATÉGIAS PARA SUPERAR SUA CRISE}

\section{MARCELO SEVAYBRICKER MOREIRA}

Resumo: Este artigo analisa um conjunto de escritos publicados nos últimos anos que identificam uma grave crise das democracias contemporâneas. Eles tratam das causas e dos sintomas desse processo de "desconsolidação democrática" e propõem algumas soluções para sua superação. O clamor pela restauração da democracia liberal destaca-se como elemento normativo comum à maior parte desses escritos. Contraposto a essas concepções institucionalistas e que redundam em duas estratégias de reconstrução da democracia liberal (o "salvacionismo elitista" e o "catecismo cívico"), este artigo assume que vivemos uma crise estrutural do chamado "capitalismo democrático", produzido pela "revolução neoliberal". Dessa última perspectiva não se deduz, todavia, nenhuma "saída" imediata para o dramático momento histórico em tela.

Palavras-chave: Democracia; Crise; Século XXI; Liberalismo; Capitalismo.

\section{DEMOCRACIES IN THE 21ST CENTURY: CAUSES, SYMPTOMS AND STRATEGIES TO OVERCOME THEIR CRISIS}

Abstract: This article analyzes papers that have been published in recent years that identify a serious crisis of contemporary democracies. They address the causes and symptoms of this "democratic deconsolidation" process and propose some solutions for overcoming it. The clamor for the restoration of liberal democracy stands out as a common normative element in most texts. Opposed to these institutionalist conceptions that result in two strategies for the reconstruction of liberal democracy ("elitist salvationism" and "civic catechism"), this article assumes that we are experiencing a structural crisis of the so-called "democratic capitalism" produced by 
the "neoliberal revolution". Following this last perspective, however, no immediate "exit" can be deduced for this current dramatic historical moment.

Keywords: Democracy; Crisis; 21st Century; Liberalism; Capitalism. Recebido: 27/05/2020 Aprovado: 09/10/2020 